\title{
Analisis Kompetensi Pedagogik Guru Pendidikan Agama Islam SMP Negeri di Kota Metro
}

\author{
Eka Suci Indria Sari \\ Ilmu Hukum Universitas Lampung \\ eka.indria@fh.unila.ac.id \\ Syarifah Nurbaiti \\ Ekonomi Pembangunan Universitas Lampung \\ syarifah.nurbaiti87@ feb.unila.ac.id \\ Rohani \\ rohani@fh.unila.ac.id \\ Ilmu Hukum Universitas Lampung
}

\begin{abstract}
Abstrak
Panelitian ini dilatarbelakangi oleh Lampiran Permendiknas -No.16 Tahun 2007 tentang Standar Kualifikasi Akademik dan Kompetensi Guru. Penelitian ini bertujuan untuk mengetahui dan menganalisis kompetensi pedagogik guru Pendidikan Agama Islam SMP Negeri di Kota Metro. Metode yang digunakan dalam penelitian ini adalah metode deskriptif dengan pendekatan kualitatif. Populasi dalam penelitian ini adalah seluruh guru SMP Negeri di Kota Metro sebanyak 30 orang yang berasal dari 10 sekolah. Teknik pengambilan sampel dengan purposive sampling sehingga diperoleh 9 guru dari 3 sekolah yaitu SMP Negeri 3 Metro, SMP Negeri 4 dan SMP Negeri 6 Metro sebagai responden dengan pertimbangan kemudahan lokasi dan komunikasi terkait pengambilan data di masa pandemi Covid-19. Teknik pengumpulan data dalam penelitian adalah observasi, kuesioner dan wawancara. Teknik analisis data meliputi data reduction, data display, dan conclusion drawing/ verification. Hasil penelitian ini menunjukan kompetensi pedagogik Guru Pendidikan Agama Islam SMP Negeri di Kota Metro berada pada kategori cenderung tinggi yaitu dengan perolehan skor total sebesar $82,05 \%$. Hasil penelitian ini diharapkan dapat dijadikan sebagai masukan bagi para pengambil kebijakan terkait kompetensi pedagogik guru Pendidikan Agama Islam.
\end{abstract}

Kata Kunci : Kompetensi Pedagogik, Guru, Pendidikan Agama Islam

\begin{abstract}
This research is motivated by the Annex to the Regulation of the Minister of National Education No.16 of 2007 concerning Academic Qualification Standards and Teacher Competencies. This study aims to determine and analyze the pedagogical competence of Islamic Religious Education teachers in State Junior High Schools in Metro City. The method used in this research is descriptive method with a qualitative approach. The population in this study were all teachers of SMP Negeri in Metro City as many as 30 people from 10 schools. The sampling technique was purposive sampling in order to obtain 9 teachers from 3 schools, namely SMP Negeri 3 Metro, SMP Negeri 4 and SMP Negeri 6 Metro as respondents
\end{abstract}


considering the ease of location and communication related to data collection during the Covid-19 pandemic. Data collection techniques in research are observation, questionnaires and interviews. Data analysis techniques include data reduction, display data, and conclusion drawing / verification. The results of this study indicate the pedagogical competence of the Islamic Religious Education Teachers of State Junior High Schools in Metro City is in the high tended category with a total score of $82.05 \%$. The results of this study are expected to be used as input for policy makers regarding the pedagogical competence of Islamic Religious Education teachers.

Keywords : Pedagogic Competence, Teacher, Islamic Religious Education 


\section{Pendahuluan}

Mutu pendidikan ditentukan salah satunya dari faktor kompetensi yang dimiliki seorang guru. Guru yang berkompeten akan lebih mampu mengelola kelasnya, sehingga belajar para peserta didik berada pada tingkat optimal (Hamalik, 2006) Menurut Undang-Undang Nomor 14 Tahun 2005 pasal 1 ayat 1 dijelaskan bahwa Guru adalah tenaga professional dengan tugas utama mendidik, mengajar, membimbing, mengarahkan, melatih, menilai dan mengevaluasi peserta didik pada pendidikan anak usia sekolah pada jalur pendidikan formal, pendidikan dasar dan pendidikan menengah. Begitu pula menurut Undang-undang Republik Indonesia nomor 20 tahun 2003 tentang Sistem Pendidikan Nasional pasal 39 ayat (2), menyatakan bahwa pendidik merupakan tenaga professional yang bertugas merencanakan dan melaksanakan proses pembelajaran, menilai hasil pembelajaran, melakukan pembimbingan dan pelatihan serta melakukan penelitian dan pengabdian kepada masyarakat, terutama bagi pendidik pada perguruan tinggi.

Berdasarkan peraturan tersebut, maka guru harus memiliki empat kompetensi salah satunya adalah kompetensi pedagogik. Kompetensi pedagogik merupakan kemampuan guru dalam pengelolaan pembelajaran peserta didik. Adapun indikator dari kompetensi pedagogik menurut Asep dan Jihad ${ }^{1}$ adalah sebagai berikut: 1) kemampuan memahami peserta didik secara mendalam, 2) kemampan merancang pembelajaran, 3) kemampuan melaksanakan pembelajaran, 4) kemampuan merancang dan melaksanakan evaluasi pembelajran, 5) kemampuan mengembangkan peserta didik untuk mengaktualisasikan berbagai potensinya. Kompetensi pedagogik berdasarkan lampiran Permendiknas Nomor 16 Tahun 2007 tentang Standar Kualifikasi Akademik dan Kompetensi Guru adalah sebagai berikut: 1) Menguasai karakteristik peserta didik dari aspek fisik, moral, spiritual, sosial, kultural, emosional, dan intelektual, 2) Menguasai teori belajar dan prinsip-prinsip pembelajaran yang mendidik, 3) Mengembangkan kurikulum yang terkait dengan mata pelajaran yang diampu, 4) Menyelenggarakan pembelajaran mendidik, memanfaatkan teknologi informasi dan komunikasi untuk kepentingan pembelajaran, 5) Memfasilitasi pengembangan potensi peserta didik untuk mengaktualisasikan berbagai potensi yang dimiliki, 6) Berkomunikasi secara efektif,

\footnotetext{
${ }^{1}$ Asep, S., \& Jihad, A. Bagaimana Menjadi calon Guru Dan Guru Professional. (Yogyakarta: Multi Pressindo, 2013), 34
} 
empatik, dan santun dengan peserta didik, 7) Menyelenggarakan penilaian dan evaluasi proses dan hasil belajar, 9) Memanfaatkan hasil penilaian dan evaluasi untuk kepentingan pembelajaran, 10) Melakukan tindakan reflektif untuk peningkatan kualitas pembelajaran. Kesepuluh indikator kompetensi pedagogik di atas harus dimiliki setiap guru, termasuk guru pendidikan agama Islam SMPN di Metro. Alasannya Agar materi Pendidikan Agama Islam yang diterima oleh peserta didik tidak menjadi beban tambahan belajar dan tidak membuat jenuh peserta didik ketika mengikuti pelajaran Pendidikan Agama Islam. ${ }^{2}$

Menurut hasil penelitian Riandhana menemukan bahwa kompetensi pedagogik Guru berpengaruh terhadap pembelajaran IPS di SMP Negeri se-Kota Palu. Hasil penelitian lain menurut penelitian Ujang Dedih dan Ai Irma Nurajijah ${ }^{3}$ menemukan bahwa terdapat hubungan yang tinggi antara tanggapan peserta didik terhadap kompetensi pedagogik guru PAI dengan motivasi belajar peserta didik mengikuti mata pelajaran PAI di SMPN 17 Kota Bandung. Menurut Fitri Yulianti ${ }^{4}$, Dalam penelitiannya menemukan bahwa terdapat hubungan yang sangat kuat dan signifikan antara kompetensi pedagogik guru PAI diSMP Negeri Kota Indramayu dengan prestasi belajar peserta didiknya. Jadi semakin tinggi tingkat kompetensi pedagogik seorang guru PAI di SMP Negeri KotaIndramayu, maka akan membuat semakin tinggi pula tingkat prestasi belajar yangdiperoleh peserta didiknya. ${ }^{5}$

Berdasarkan hasil penelitian tersebut, jelaslah bahwa kompetensi guru khususnya kompetensi pedagogik sangat penting dimiliki oleh guru yang professional, sehingga dapat melaksanakan pembelajaran dengan efektif dan efisien dan mutu pendidikan pun akan meningkat dengan lebih optimal. Kualitas para pendidik di Indonesia menempati urutan ke-14 dari 14 negara berkembang di dunia. Sementara itu, jumlah guru mengalami peningkatan sebanyak 382\% dari 1999/2000 menjadi sebanyak 3 juta orang lebih, dan di antaranya masih terdapat $25 \%$ guru yang belum memenuhi

\footnotetext{
${ }^{2}$ Ramayulis, Profesi dan Etika Keguruan. (Jakarta: Kalam Mulia, 2013), 213

${ }^{3}$ Ujang Dedih dan Ai Irma Nurajijah, Kompetensi Paedagogik Guru Pendidikan Agama Islam Terhadap Motivasi Belajar Siswa SMP. Jurnal Perspektif, (2. 1, 2018), 72-79.

${ }^{4}$ Fitri Yulianti, Prinsip Kontinuitas dalam Evaluasi Proses Pembelajaran. Al-Ishlah: Jurnal Pendidikan, (10,1, 2018), 89-102

${ }^{5}$ Riandhana, Pengaruh Kompetensi Pedagogik dan Kompetensi Profesional Guru terhadap Pembelajaran IPS di SMP Negeri Kota Palu. Katalogis, (4, 1 2016), 23
} 
syarat kualifikasi akademik, serta $52 \%$ belum memiliki sertifikat profesi ${ }^{6}$. Disisi lain, kompetensi pendidik di negara dengan jumlah populasi terbanyak keempat di dunia ini tergolong sangat rendah. Data Kementerian Pendidikan dan Kebudayaan menunjukkan, diantara 1,6 juta peserta uji kompetensi guru, lebih dari 1,3 juta diantaranya memiliki nilai di bawah 60, dari rentang nilai 0 hingga 100. Dari ujian ini pula, hanya 192 guru yang mendapat nilai di atas 90. Sementara hampir 130.000 di antaranya hanya mampu memperoleh nilai di bawah 30. Rendahnya kapabilitas tenaga pengajar ini berimbas pada kualitas pendidikan di setiap daerah. ${ }^{7}$

Dalam penelitian ini, penelitian dilakukan pada jenjang sekolah menengah pertama (SMP), pada umumnya peserta didiknya berumur antara 12-16 yang lazim dikenal dengan masa remaja atau akil baligh. Pada masa tersebut berdasarkan psikologi perkembangan manusia merupakan tahap pembentukan watak dan pendidikan agama (usia 12-20). Pada fase ini anak mulai mampu membedakan yang baik dan yang buruk. Proses edukasi fase ini adalah memberikan model, mode, dan modus yang islami pada anak tersebut, sehingga ia mampu hidup "remaja" ditengahtengah masyarakat tanpa meninggalkan kode etis Islaminya. ${ }^{8}$

Penelitian ini dilaksanakan pada SMP Negeri yang ada di Kota Metro yang berjumlah 10 (Sepuluh). Akan tetapi penelitian ini hanya memilih 3 (tiga) SMP Negeri yang mewakili tiga wilayah yaitu pusat kota, pusat pendidikan, dan sudut perkotaan. Hal tersebut dikarenakan semua SMP Negeri yang ada di Kota Metro tersebut terakreditasi A, sehingga pemilihan lokasi penelitian berdasarkan perwakilan wilayah. Untuk lebih jelasnya dapat dilihat pada Tabel berikut.

Lokasi Penelitian ${ }^{9}$

\begin{tabular}{|c|l|l|c|l|}
\hline No & Nama SMP & \multicolumn{1}{|c|}{ Alamat } & Akreditasi & \multicolumn{1}{|c|}{ Lokasi } \\
\hline 1 & SMPN 3 & $\begin{array}{l}\text { Jl. AR. Prawira Negara No } \\
\text { 1 Kecamatan Metro Pusat }\end{array}$ & A & $\begin{array}{l}\text { Wilayah Pusat } \\
\text { Kota }\end{array}$ \\
\hline 2 & SMPN 4 & $\begin{array}{l}\text { Jl. Paria 15 A Iring Mulyo } \\
\text { Kecamatan Metro Timur }\end{array}$ & A & $\begin{array}{l}\text { Wilayah Pusat } \\
\text { Pendidikan }\end{array}$ \\
\hline 3 & SMPN 6 & $\begin{array}{l}\text { Jl. Patimura 29 Banjarsari, } \\
\text { Kecamatan Metro Utara }\end{array}$ & A & $\begin{array}{l}\text { Wilayah Sudut } \\
\text { Perkotaan }\end{array}$ \\
\hline
\end{tabular}

\footnotetext{
${ }^{6}$ Raharjo, Evaluasi Trend Kualitas Pendidikan di Indonesia. Jurnal Penelitian dan Evaluasi Pendidikan, (16,2, 2018), 511-532

${ }^{7}$ Ramadhani, W. P, Pengaruh Penggunaan Media Komik dan Motivasi Belajar terhadap Hasil Belajar Matematika Siswa SMP. JUPITEK: Jurnal Pendidikan Matematika, (2, 2, 2019), 77-86.

${ }^{8}$ Mujib, \& Mudzakir, Nuasa-nuasa psikologi Islam. (Raja Grafindo Persada, 2001), 34

${ }^{9}$ UPTD Kota Metro Provinsi Lampung Tahun 2019/2020
} 


\section{Metode Penelitian}

Penelitian ini menggunakan metode penelitian kualitatif. Penelitian kualitatif ini bertujuan mendeskripsikan kompetensi pedagogik guru pendidikan agama Islam SMPN di Metro dan kesesuaiannya terhadap Peraturan Menteri No.16 Tahun 2007 tentang Standar Kualifikasi Akademik dan Kompetensi Guru. Sumber data dalam penelitian ini adalah hasil observasi, kuesioner dan wawancara dengan guru. Subjek dalam penelitian ini mencakup seluruh guru Pendidikan Agama Islam SMPN di Metro. Teknik analisis data yang digunakan dalam penelitian ini adalah teknik analisis deskriptif. Langkah-langkah analisis ditunjukan pada Gambar 1 berikut.

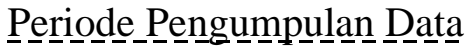

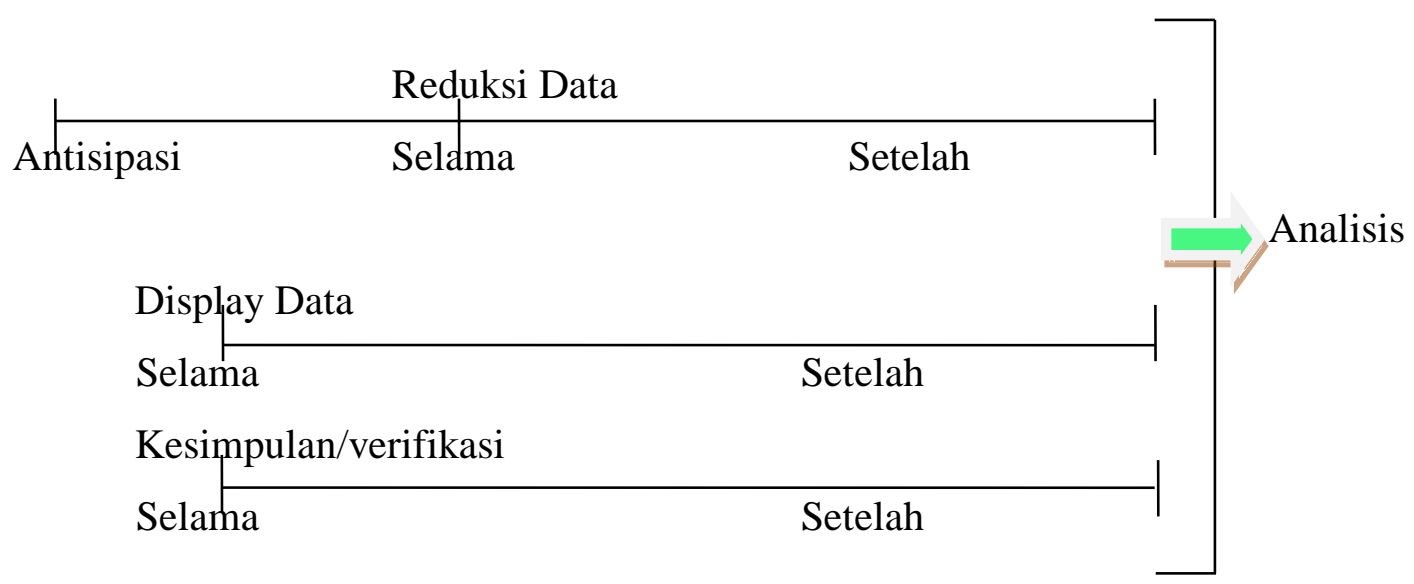

Gambar 1. Komponen dalam analisis data (flow model)

Berdasarkan gambar tersebut terlihat bahwa, setelah peneliti melakukan pengumpulan data, maka peneliti melakukan antisipatory sebelum melakukan reduksi data. Selanjutnya model interaktif dalam analisis data ditunjukan pada Gambar 2 berikut.

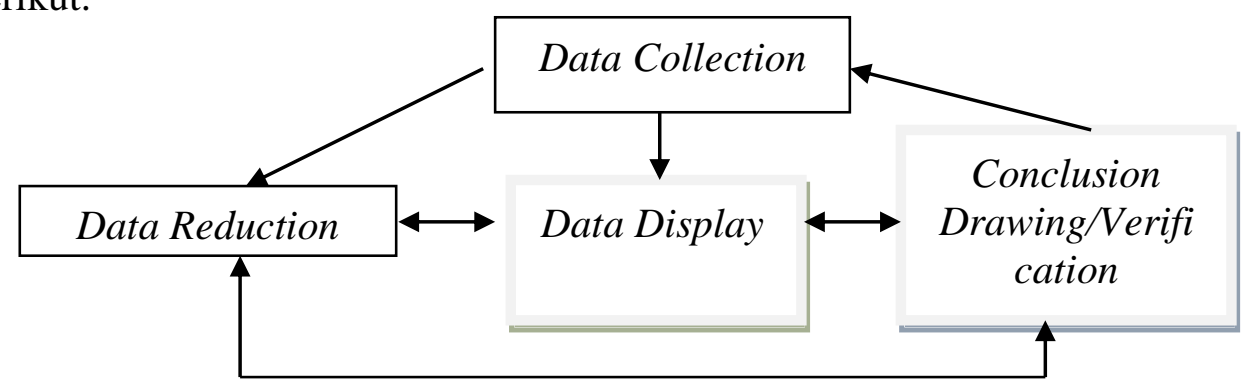

Gambar 2. Komponen dalam analisis data (interactive model) 


\section{Deskripsi Kompetensi Pedagogik Guru Pendidikan Agama Islam SMPN di Kota Metro}

Variabel kompetensi pedagogik dalam penelitian ini diukur dengan sepuluh indikator yaitu menguasai karakteriktik peserta didik, menguasai teori belajar dan prinsip-prinsip pembelajaran yang mendidik, mengembangkan kurikulum terkait dengan mata pelajaran yang diampu, menyelenggarakan pembelajaran yang mendidik, memfasilitasi pengembangan potensi peserta didik untuk mengaktualisasikan berbagai yang dimiliki, berkomunikasi secara efektif, empatik dan santun dengan peserta didik, menyelenggarakan penilaian dan evaluasi proses dan hasil belajar, memanfaatkan hasil penilaian dan evaluasi untuk kepentingan pembelajaran, dan melakukan tindakan reflektif untuk peningkatan kualitas. Hasil pengolahan data yang telah dilakukan pada saat studi lapangan, menunjukan kompetensi pedagogik guru Pendidikan Agama Islam SMPN di Kota Metro berada pada kategori cenderung tinggi dengan skor persentase sebesar $82,05 \%$.

\section{Pembahasan}

Berdasarkan hasil pengolahan data dapat diketahui bahwa kompetensi pedagogik Guru Pendidikan Agama Islam SMPN di Kota Metro berada pada kategori cenderung tinggi. Artinya guru Pendidikan Agama Islam SMPN di Kota Metro 1) Mampu menguasai karakteriktik peserta didik, 2) Menguasai teori belajar dan prinsipprinsip pembelajaran yang mendidik, 3) Mengembangkan kurikulum terkait dengan mata pelajaran yang diampu, 4) Menyelenggarakan pembelajaran yang mendidik, 5) Memanfaatkan teknologi informasi dan komunikasi untuk kepentingan pembelajaran, 6) Memfasilitasi pengembangan potensi peserta didik untuk mengaktualisasikan berbagai yang dimiliki, 7) Berkomunikasi secara efektif, empatik dan santun dengan peserta didik, 8) Menyelenggarakan penilaian dan evaluasi proses dan hasil belajar 9) memanfaatkan hasil penilaian dan evaluasi untuk kepentingan pembelajaran, dan 10) melakukan tindakan reflektif untuk peningkatan kualitas.

Dari sepuluh indikator kompetensi pedagogik, indikator memfasilitasi pengembangan potensi peserta didik untuk mengaktualisasikan berbagai yang dimiliki merupakan indikator yang paling tinggi dengan skor sebesar $88,00 \%$. Hal ini berarti Guru Pendidikan Agama Islam SMPN di Kota Metro sudah mampu 1) menyediakan 
berbagai kegiatan pembelajaran untuk mendorong peserta didik mencapai prestasi secara optimal dan 2) menyediakan berbagai kegiatan pembelajaran untuk mengaktualisasikan potensi peserta didik, termasuk kreativitasnya. Hasil ini memperkua hasil-hasil penelitian sebelumnya yaitu penelitian Suhandani \& Julia ${ }^{10}$ dan Ahmad. ${ }^{11}$

Hasil ini diperkuat pernyataan dalam wawancara dengan Bapak Ilham, S.Ag, M.Pd.I yang merupakan Guru PAI SMPN 3 Metro, beliau mengungkapkan bahwa:

Guru Pendidikan Agama Islam di Kota Metro sudah mampu memfasilitasi pengembangan potensi peserta didik untuk mengaktualisasikan berbagai hal yang dimiliki, terkait ini terlihat dalam proses kegiatan pembelajaran dimana guru selalu memotivasi dan mengarahkan siswa untuk selalu mengembangkan dan mengoptimalkan potensi yang mereka miliki dalam dalam menyiapkan masa depan yang lebih baik. ${ }^{12}$

Sejalan dengan pernyataan tersebut, Bapak Sunanto, S.Pd., M. Pd selaku Kepala

Sekolah SMPN 4 Kota Metro dalam wawancara juga mengungkapkan:

Selama proses pembelajaran Agama Islam, guru-guru di SMP Metro memfasilitasi pengembangan potensi peserta didik untuk mengaktualisasikan berbagai hal yang dimiliki dengan cara memberikan 1) bimbingan karir dalam upaya mengarahkan siswa untuk menentukan pilihan jenis pendidikan dan jenis pekerjaan sesuai dengan kemampuannya, 2) latihan-latihan praktis terhadap siswa dengan orientasi kepada kondisi (tuntutan) lingkungan dan 3) Penyusunan kurikulum yang komprehensif dengan mengembangkan kurikulum muatan lokal. ${ }^{13}$

Indikator tertinggi kedua adalah indikator menyelenggarakan penilaian dan evaluasi proses dan hasil belajar dengan perolehan skor sebesar 87,00\%. Hal ini berarti Guru Pendidikan Agama Islam SMPN di Kota Metro sudah mampu 1) memahami prinsip-prinsip penilaian dan evaluasi proses dan hasil belajar sesuai dengan karakteristik mata pelajaran yang diampu. 2) menentukan aspek-aspek proses dan hasil belajar yang penting untuk dinilai dan dievaluasi sesuai dengan karakteristik mata pelajaran yang diampu. 3) menentukan prosedur penilaian dan evaluasi proses dan hasil belajar. 4) mengembangkan instrumen penilaian dan evaluasi proses dan hasil belajar. 5) mengadministrasikan penilaian proses dan hasil belajar secara berkesinambungan

\footnotetext{
${ }^{10}$ Suhandani \& Julia Identifikasi Kompetensi Guru Sebagai Cerminan Profesionalisme Tenaga Pendidik Di Kabupaten Sumedang (Kajian Pada Kompetensi Pedagogik). Mimbar Sekolah Dasar, (1,2, 2014), 128-141.

${ }^{11}$ Problematika Kompetensi Pedagogik Guru Matematika ditinjau Dari Perspektif Peserta Didik Di Smk Muhammadiyah 2 Malang. In Prosiding Seminar Nasional Pendidikan Matematika (Vol. 1, 2018).

12 wawancara dengan Bapak Ilham

${ }^{13}$ Wawancara dengan Bapak Sunanto
} 
dengan mengunakan berbagai instrumen. 6) menganalisis hasil penilaian proses dan hasil belajar untuk berbagai tujuan. dan 7) melakukan evaluasi proses dan hasil belajar. Kompetensi pedagogik guru yang berkaitan dengan menyelanggarakan penilaian dan evaluasi proses dan hasil belajar harus berpatokan pada prinsip-prinsip umum evaluasi yang meliputi 1) kontinuitas, 2) komprehensif, 3) adil dan objektif, 4) kooperatif dan 5) praktis. Arifin ${ }^{14}$ dan Fitrianti ${ }^{15}$.

Hasil ini diperkuat pernyataan dalam wawancara dengan Ibu Sumarni, S.Pd.I yang merupakan guru SMPN 4 Metro, beliau mengungkapkan bahwa:

Guru-guru di SMPN di Kota Metro sudah mampu menyelenggarakan penilaian dan evaluasi proses dan hasil belajar dengan baik. Hal ini terlihat ketika penilaian dan evaluasi dilakukan pada saat pembelajaran berlangsung dan menilai dengan baik hasil siswa meliputi ranah kognitif, afektif dan psikomotorik dengan penilaian tes, non tes dan portofolio.

Sejalan dengan pernyataan tersebut, Indra seorang siswa SMPN 4 Kota Metro dalam wawancara juga mengungkapkan:

Dalam proses maupun setelah pembelajaran berakhir guru guru Pendidikan Agama Islam menyelenggarakan penilaian dan evaluasi proses dan hasil belajar. Penilaian dilakukan guru dengan cara penilaian kegiatan siswa, penggunaan portofolio, kegiatan praktek dan tugas tertulis. Penilaian hasil belajar peserta didik mencakup kompetensi sikap, pengetahuan, dan keterampilan.

Indikator tertinggi ketiga adalah indikator menguasai karakteriktik peserta didik dari aspek fisik, moral, spiritual, sosial, kultural, emosional dan intelektual dengan perolehan skor total sebesar 86,00\%. Hal ini berarti Guru Pendidikan Agama Islam di Metro telah mampu 1) memahami karakteristik peserta didik yang berkaitan dengan aspek fisik, intelektual, sosial-emosional, moral, spiritual, dan latar belakang sosial budaya. 2) mengidentifikasi potensi peserta didik dalam mata pelajaran yang diampu. 3) mengidentifikasi bekal-ajar awal peserta didik dalam mata pelajaran yang diampu dan 4) mengidentifikasi kesulitan belajar peserta didik dalam mata pelajaran yang diampu. Aldarmono ${ }^{16}$ dan Hamzah ${ }^{17}$, menyatakan bahwa Kompetensi pedagogik guru

\footnotetext{
${ }^{14}$ Arifin, Evaluasi pembelajaran mata pelajaran PAI siswa kelas IX di SMP Islam Sultan Agung Sukolilo Pati (Doctoral dissertation, UIN Walisongo) 2009.

${ }^{15}$ Fitriyani, Prinsip Kontinuitas Dalam Evaluasi Proses Pembelajaran. Al-Ishlah: Jurnal Pendidikan, (10, 1, 2018), 89-102,

${ }^{16}$ Alarmono Identifikasi Gaya Kognitif (cognitive style) Peserta Didik dalam Belajar. Al-Mabsut: Jurnal Studi Islam dan Sosial, (3,1, 2012), 63-69
} 
yang berkaitan dengan memahami karakter peserta didik adalah unsur yang penting dalam proses pembelajaran, karena setiap peserta didik memiliki kemampuan dan karakter yang berbeda. Karakteristik peserta didik adalah aspek atau kualitas perseorangan peserta didik yang terdiri dari minat, sikap, motivasi belajar, gaya belajar, kemampuan berfikir, dan kemampuan awal yang dimiliki (, 2012;, 2007).

Hasil ini diperkuat pernyataan dalam wawancara dengan Bapak Hasyim As'ari, S.Ag yang merupakan guru SMPN 6 Metro, beliau mengungkapkan bahwa:

Guru PAI di Kota Metro sudah mampu menguasai karakteriktik peserta didik dari aspek fisik, moral, spiritual, sosial, kultural, emosional dan intelektual, hal ini terlihat dalam proses pembelajaran maupun interaksi sehari-hari di sekolah guru sudah mampu mengenali dan memahami siswa berdasarkan aspek fisik, moral, spiritual, sosial, kultural, emosional dan intelektual sehingga interaksi dalam proses pembelajaran terjalin dengan baik dan harmonis. ${ }^{18}$

Sejalan dengan pernyataan tersebut, Ibu Lusi Andriyani, SE., M. Pd selaku Kepala Sekolah SMPN 3 dalam wawancara juga mengungkapkan:

Berkaitan dengan kompetensi pedagogik dalam menguasai karakteriktik peserta didik dari aspek fisik, moral, spiritual, sosial, kultural, emosional dan intelektual, guru-guru Pendidikan Agama Islam SMPN di Metro sudah mampu melakukanya, hal ini terlihat dari interaksi antara guru dan siswa baik di lingkungan sekolah maupun dalam proses pembelajaran Agama Islam. ${ }^{19}$

Indikator tertinggi keempat adalah indikator memanfaatkan hasil penilaian dan evaluasi untuk kepentingan pembelajaran dengan perolehan skor sebesar 85,50\%. Senada dengan temuan di atas temuan Purwanto ${ }^{20}$, dan Widoyoko ${ }^{21}$, Guru Pendidikan Agama Islam di Metro sudah mampu 1) menggunakan informasi hasil penilaian dan evaluasi untuk menentukan ketuntasan belajar. 2) menggunakan informasi hasil penilaian dan evaluasi untuk merancang program remedial dan pengayaan. 3) mengkomunikasikan hasil penilaian dan evaluasi kepada pemangku kepentingan dan 4) memanfaatkan informasi hasil penilaian dan evaluasi pembelajaran untuk meningkatkan kualitas

\footnotetext{
${ }^{17}$ Hamzah, Profesi Kependidikan, Problema, Solusi, dan Reformasi Pendidikan di Indonesia. (Bumi Aksara: Jakarta 2007), 54

${ }^{18}$ Wawancara dengan Bapak Hasyim As'ari

${ }^{19}$ Wawancara dengan Ibu Lusi Andriyani

${ }^{20}$ Purwanto, Penggunaan Model Assessment Portofolio dalam Penilaian Proses dan Hasil Belajar Program Linear. (Jurnal Mimbar Pendidikan, 2006)

${ }^{21}$ Widoyoko, Evaluasi program pembelajaran. (Yogyakarta: Pustaka Pelajar, 2009), 67
} 
pembelajaran. Guru dalam melaksanakan penilaian dituntut membuat laporan tentang hasil penilaiannya. Laporan ini akan dimanfaatkan oleh peserta didik, orang tua, dan pendidik. Bagi pendidik laporan hasil penilaian akan digunakan untuk mendiagnosis hasil belajar peserta didik, memprediksi masa depan peserta didik sebagai umpan balik proses pembelajaran dan kurikulum, kepentingan seleksi dan sertifiksi, dan untuk menetapkan kebijakan yang terkait dengan pengelolaan pembelajaran

Hasil ini diperkuat pernyataan dalam wawancara dengan Bapak Hengki Irawan, S.Pd.I yang merupakan guru SMPN 3 Metro, beliau mengungkapkan bahwa:

Guru-guru PAI di Kota Metro sudah mampu memanfaatkan hasil penilaian dan evaluasi untuk kepentingan pembelajaran, hal ini terlihat dimana guru sudah merancang pembelajaran dan remedial berdasarkan hasil penilaian dan evaluasi untuk memperbaiki bahkan meningkatkan pemahaman siswa terkait materi yang dipelajari.

Indikator tertinggi kelima adalah indikator melakukan tindakan reflektif untuk peningkatan kualitas dengan perolehan skor sebesar 85,00\%. Hal ini berarti Guru Pendidikan Agama Islam di Metro sudah mampu 1) melakukan refleksi terhadap pembelajaran yang telah dilaksanakan. 2) memanfaatkan hasil refleksi untuk perbaikan dan pengembangan pembelajaran dalam mata pelajaran yang diampu dan 3) melakukan penelitian tindakan kelas untuk meningkatkan kualitas pembelajaran dalam mata pelajaran yang diampu. Hasil penelitian ini mendukung dan sejalan dengan penelitian sebelumnya yaitu penelitian Sriyanto, $\mathrm{dkk}^{22}$ (2018) dan Balqis, Ibrahim ${ }^{23}$ (2014).

Hasil ini diperkuat pernyataan dalam wawancara dengan Ibu Munawaroh, S.Ag yang merupakan guru SMPN 4 Metro, beliau mengungkapkan bahwa:

Guru-guru PAI di Kota Metro sudah mampu melakukan tindakan reflektif untuk peningkatan kualitas. Tindakan reflektif yang dilakukan guru-guru PAI di Kota Metro yaitu meninjau kembali proses pembelajaran yang telah dilakukan. Manfaat tindakan reflektif adalah guru dapat mengevaluasi proses pembelajaran, termasuk media, metode, materi, siswa, bahkan penampilan guru sendiri.

Indikator tertinggi keenam adalah indikator berkomunikasi secara efektif, empatik dan santun dengan peserta didik dengan perolehan skor sesar 81, 00\%. Hal ini berarti Guru

\footnotetext{
${ }^{22}$ Sriyanto,dkk Peningkatan profesionalisme guru ekonomi dalam pembelajaran di SMA Kabupaten Semarang. JPPM (Jurnal Pengabdian dan Pemberdayaan Masyarakat), (2, 2, 2018), 357-362

${ }^{23}$ Balqis, Ibrahim, Kompetensi Pedagogik Guru dalam Meningkatkan Motivasi Belajar Siswa pada SMPN 3 Ingin Jaya Kabupaten Aceh Besar. Jurnal Administrasi Pendidikan: Program Pascasarjana Unsyiah, (2, 1, 2014), 76
} 
Pendidikan Agama Islam di Metro sudah mampu 1) memahami berbagai strategi berkomunikasi yang efektif, empatik, dan santun, secara lisan, tulisan, dan/atau bentuk lain dan 2) berkomunikasi secara efektif, empatik, dan santun dengan peserta didik dengan bahasa yang khas dalam interaksi kegiatan/permainan yang mendidik yang terbangun secara siklikal dari (a) penyiapan kondisi psikologis peserta didik untuk ambil bagian dalam permainan melalui bujukan dan contoh, (b) ajakan kepada peserta didik untuk ambil bagian, (c) respons peserta didik terhadap ajakan guru, dan (d) reaksi guru terhadap respons peserta didik, dan seterusnya. Hasil penelitian ini mendukung dan sejalan dengan penelitian sebelumnya yaitu penelitian Yusuf (2019), Ashsiddiqi, (2012) dan Muspiroh, (2016).

Hasil ini diperkuat pernyataan dalam wawancara dengan Ibu Dra. Supiyatin yang merupakan guru SMPN 6 Metro, beliau mengungkapkan bahwa:

Guru-guru PAI di Kota Metro sudah mampu berkomunikasi secara efektif, empatik dan santun dengan peserta didik, hal ini terlihat dalam proses pembelajaran sudah terjadi pertukaran informasi, ide, perasaan yang menghasilkan perubahan sikap sehingga terjalin sebuah hubungan baik antara guru dan dan peserta didik. Selain itu peserta didik sudah mampu menerima pesan yang disampaikan guru.

Sejalan dengan pernyataan tersebut, Ayuningtyas seorang siswa SMPN 3 dalam wawancara juga mengungkapkan:

Dalam proses pembelajaran, dilingkungan sekolah ataupun dalam berinteraksi antara guru dan siswa, guru-guru SMPN di Metro selalu menggunakan kata-kata yang baik dan lemah lembut sehingga kami bisa nyaman belajar dengan bapak dan ibu guru.

Indikator tertinggi ketujuh adalah indikator mengembangkan kurikulum terkait dengan mata pelajaran yang diampu dengan perolehan skor sesar $80.00 \%$. Hal ini berarti Guru Pendidikan Agama Islam di Metro sudah mampu 1) memahami prinsip-prinsip pengembangan kurikulum. 2) menentukan tujuan pembelajaran yang diampu. 3) menentukan pengalaman belajar yang sesuai untuk mencapai tujuan pembelajaran yang diampu.4) memilih materi pembelajaran yang diampu yang terkait dengan pengalaman belajar dan tujuan pembelajaran. 5) menata materi pembelajaran secara benar sesuai dengan pendekatan yang dipilih dan karakteristik peserta didik namun belum mampu mengembangkan indikator dan instrumen penilaian. Hasil penelitian ini mendukung 
dan sejalan dengan penelitian sebelumnya yaitu penelitian Ulla ${ }^{24}$, Norsidi, \& Paiman ${ }^{25}$, dan Afandi \& Wahyuningsih ${ }^{26}$.

Hasil ini diperkuat pernyataan dalam wawancara dengan Bapak Al Amin Saputra, S.Pd.I yang merupakan guru SMPN 3 Metro, beliau mengungkapkan bahwa:

Guru-guru PAI di Kota Metro sudah mampu mengembangkan kurikulum terkait dengan mata pelajaran yang diampu. Hal ini terlihat ketika guru-guru PAI merencanakan dan menyusun kurikulum kegiatan yang dilakukan agar kurikulum yang dihasilkan dapat menjadi bahan ajar dan acuan yang digunakan untuk mencapai tujuan pembelajaran agama Islam. ${ }^{27}$

Sejalan dengan pernyataan tersebut, Ibu Yunani, S. Pd selaku Kepala Sekolah SMPN 6 Metro dalam wawancara juga mengungkapkan:

Berkaitan dengan kompetensi pedagogik dalam mengembangkan kurikulum terkait dengan mata pelajaran yang diampu, guru-guru Pendidikan Agama Islam di Metro sudah sangat baik. Sebelum kegiatan belajar mengajar guru-guru sudah menyiapkan rencana pembelajaran dan tujuan pembelajaran Agama Islam mengacu kepada kurikulum nasional. $^{28}$

Indikator tertinggi kedelapan adalah indikator memanfaatkan teknologi informasi dan komunikasi untuk kepentingan pembelajaran dengan perolehan skor sebesar 78, 66\%. Hal ini berarti Guru Pendidikan Agama Islam di Metro sudah mampu memanfaatkan teknologi informasi dan komunikasi dalam pembelajaran yang diampu. Kemampuan guru yang berkaitan dengan pemanfaatan media pembelajaran meliputi kemampuan guru menggunakan media audio, visual, audiovisual, dan multimedia dalam proses belajar mengajar. Dalam temuan Husain ${ }^{29}$ dan juga Restiyani ${ }^{30}$ Guru yang dapat memanfaatkan media pembelajaran, diharapkan dapat membantu dalam

\footnotetext{
${ }^{24}$ Ula, Analisis Kompetensi Pedagogik Guru Pada Aspek Pengembangan Kurikulum Terkait Mata Pelajaran Yang Di Ampu Melalui Rencana Pelaksanaan Pembelajaran (Studi Pada Guru Produktif Pemasaran di SMK Negeri 1 Boyolangu Tulungagung). SKRIPSI Jurusan Manajemen-Fakultas Ekonomi $U M, 2017$.

${ }^{25}$ Norsidi, \& Paiman, Analisis Kompetensi Pedagogik Guru Mata Pelajaran Geografi Sekolah Menengah Atas (SMA) Sebagai Pelaksana Kurikulum 2013 Di Kabupaten Ketapang. Sosial Horizon: Jurnal Pendidikan Sosial, (5,2, 2018), 202-216

${ }^{26}$ Afandi, M., \& Wahyuningsih, S, Analisis Kompetensi Pedagogik Guru SD di UPTD Pendidikan Banyumanik Kota Semarang. Elementray, $(6,1,2018), 1-21$

${ }^{27}$ Wawancara dengan Bapak Al Amin Saputra

${ }^{28}$ Wawancara dengan Ibu Yunani

${ }^{29}$ Husain, Pemanfaatan teknologi informasi dan komunikasi dalam pembelajaran di SMA Muhammadiyah Tarakan. Jurnal Kebijakan dan Pengembangan Pendidikan, (2,2, 2014), 23

${ }^{30}$ Restiyani, Profil Pemanfaatan Teknologi Informasi dan Komunikasi (TIK) sebagai Media dan Sumber Pembelajaran oleh Guru Biologi. EDUSAINS, (6, 1, 2014), 49-66
} 
penyampaian pembelajaran. Sehingga diharapkan dapat menjadikan peserta didik lebih bersemangat dan mudah memahami pelajaran.

Hasil ini diperkuat pernyataan dalam wawancara dengan Ibu Markatun, S.Ag yang merupakan guru SMPN 4 Metro, beliau mengungkapkan bahwa:

Guru-guru PAI di Kota Metro sudah mampu memanfaatkan teknologi informasi dan komunikasi untuk kepentingan pembelajaran. Hal ini terlihat ketika dalam proses pembelajara Agama Islam guru sudah menggunakan labtop, LCD Proyektor, Komputer untuk mencari sumber-sumber materi pelajaran Agama Islam. ${ }^{31}$

Sejalan dengan pernyataan tersebut, Intan Rachmawati seorang siswa SMPN 6 Metro dalam wawancara juga mengungkapkan:

Dalam kegiatan pembelajaran Agama Islam, guru-guru Pendidikan Agama Islam sudah sangat memanfaatkan teknologi seperti internet, komputer, leptop, handphone dan media PPT. Hal ini ditambah lagi kondisi saat ini yang mengharuskan pembelajaran daring karena wabah Virus Covid 19. ${ }^{32}$

Indikator tertinggi sembilan adalah indikator menyelenggarakan pembelajaran yang mendidik perolehan skor sesar 77,00\%. Hal ini berarti guru Pendidikan Agama Islam di Metro sudah mampu 1) memahami prinsip-prinsip perancangan pembelajaran yang mendidik. 2) mengembangkan komponen-komponen rancangan pembelajaran. 3) menyusun rancangan pembelajaran yang lengkap, baik untuk kegiatan di dalam kelas, laboratorium, maupun lapangan. 4) melaksanakan pembelajaran yang mendidik di kelas, di laboratorium, dan di lapangan dengan memperhatikan standar keamanan yang dipersyaratkan dan 5) mengambil keputusan transaksional dalam pembelajaran yang diampu sesuai dengan situasi yang berkembang, namun belum mampu menggunakan media pembelajaran dan sumber belajar yang relevan dengan karakteristik peserta didik dan mata pelajaran yang diampu untuk mencapai tujuan pembelajaran secara utuh. Salah satu kemampuan guru dalam menyelanggarakan pembelajaran yang mendidik yaitu dengan melihat kemampuan guru dalam mengelola kelas. Menelaah pandangan Arikunto $^{33}$ dan Sujana ${ }^{34}$, pengelolaan kelas berarti suatu usaha yang dilaksanakan penanggung jawab kegiatan belajar mengajar atau yang membantunya dengan maksud agar tercapai suatu kondisi optimal sehingga terlaksana kegiatan belajar mengajar dapat

\footnotetext{
${ }^{31}$ Wawancara dengan Ibu Markatun

${ }^{32}$ Wawancara dengan Intan Rachmawati

33 Arikunto, Pengelolaan Kelas dan Siswa Pendekatan Praktek. (Rineka Cipta: Jakarta, 2006)

${ }^{34}$ Sujana, Efektivitas Pengelolaan Kelas. Jurnal Pendidikan Penabur, (1, 1, 2002), 64-80
} 
dicapai seperti yang diharapkan. Keterampilan pengelolaan kelas terbagi menjadi dua keterampilan meliputi: pertama, keterampilan yang berhubungan dengan penciptaan dan pemeliharaan kondisi belajar yang optimal. Kedua, keterampilan yang berhubungan dengan pengembangan kondisi belajar yang optimal. ${ }^{35}$

Hasil ini diperkuat pernyataan dalam wawancara dengan Ibu Ummi Kalsum, S.Pd.I yang merupakan guru SMPN 6 Metro, beliau mengungkapkan bahwa:

Guru-guru PAI di Kota Metro sudah mampu menyelenggarakan pembelajaran yang mendidik. Hal ini terlihat guru sudah mampu merancang pembelajaran, mengimplementasikan pembelajaran, melakukan penilaian proses dan hasil pembelajaran, dan pemanfaatan hasil penilaian untuk melakukan perbaikan secara sistematis dan berkelanjutan, sehingga dapat memfasilitas perkembangan karakter, soft skills dan pembentukan hard skills. ${ }^{36}$

Sejalan dengan pernyataan tersebut, Rizki Zulfikar seorang siswa SMPN 3 Metro dalam wawancara juga mengungkapkan:

Dalam proses Pembelajaran Guru pendidikan Agama Islam telah melakukan pembelajaran yang mendidik hal ini dirasakanya guru menyampaikan pembelajaran secara runtut sehingga materi yang disampaikan guru mudah dipahami, guru memberikan kesempatan kepada peserta didik untuk bertanya, mempraktekan dan berinteraksi dengan peserta didik yang lain, baik di dalam maupun diluar kelas. ${ }^{37}$

Indikator terakhir ialah indikator menguasai teori belajar dan prinsip-prinsip pembelajaran yang mendidik dengan peolehan skor sebesar 67,50\%. Hal ini berarti Guru Pendidikan Agama Islam di Metro sudah mampu memahami berbagai teori belajar dan prinsip-prinsip pembelajaran yang mendidik terkait dengan mata pelajaran yang diampu, namun belum mampu menerapkan berbagai pendekatan, strategi, metode, dan teknik pembelajaran yang mendidik secara kreatif dalam mata pelajaran yang diampu. Menurut Dirman \& Juarsih ${ }^{38}$, Hanafy ${ }^{39}$ dan Nahar $^{40}$, berkaitan dengan hal ini guru memberikan kesempatan kepada peserta didik untuk menguasai materi pembelajaran sesuai usia dan kemampuan belajarnya mengenai pengaturan proses pembelajaran dan aktivitas yang bervariasi dan guru selalu memastikan tingkat

\footnotetext{
${ }^{35}$ Djamarah, S. B., \& Zain, A, Belajar dan Pembelajaran. (Jakarta: Rineka Cipta, 2002),154

${ }^{36}$ Wawancara degan Ibu Ummi Kalsum

${ }^{37}$ Wawancara dengan Rizki Zulfikar

${ }^{38}$ Dirman, D., \& Juarsih, C, Teori Belajar dan Prinsip-prinsip Pembelajaran yang Mendidik. (Jakarta: Rineka Cipta. 2014), 23

${ }^{39}$ Hanafy, Konsep Belajar dan Pembelajaran. Lentera Pendidikan: Jurnal Ilmu Tarbiyah dan Keguruan, (17,1, 2014), 66-79

${ }^{40}$ Penerapan Teori Belajar Behavioristik dalam Proses Pembelajaran. NUSANTARA: Jurnal Ilmu

Pengetahuan Sosial, (1, 1, 2016), 76.
} 
pemahaman peserta didik terhadap materi pembelajaran tertentu dengan menyesuaikan aktivitas pembelajaran berikutnya berdasarkan tingkat pemahaman tersebut

Hasil ini diperkuat pernyataan dalam wawancara dengan Bapak Sunanto, S.Pd., M. Pd Selaku Kepala Sekolah SMPN 4 beliau mengungkapkan bahwa:

Guru-guru pendidikan Agama Islam di Metro sudah menguasai teori belajar dan prinsip-prinsip pembelajaran yang mendidik hal ini terlihat dari semua guru Agama Islam di Metro berasal dari jurusan pendidikan yang notabennya pada saat kuliah mereka sudah dibekali oleh teori belajar seperti teori belajar piaget, terori belajar humanistik dll semasa kuliah. Didalam proses pembelajaran terlihat dari cara guru memperlakukan siswa sesuai dengan teori perkembangan anak. ${ }^{41}$

\section{Penutup}

Berdasarkan hasil pengolahan dan analisis data peneliti dapat menyimpulkan sebagai berikut 1) Kompetensi pedagogik Guru Pendidikan Agama Islam di Kota Metro berada pada kategori cenderung tinggi yaitu dengan perolehan skor total sebesar 82,05\% yang artinya kompetensi pedagogik Guru Pendidikan Agama Islam di Kota Metro sudah sesuai dengan Kompetensi Pedagogik Guru menurut Peraturan Menteri Pendidikan Nasional No. 16 tahun 2007. 2) Kompetensi pedagogik dalam mengembangkan kurikulum terkait dengan mata pelajaran yang diampu terdapat satu indikator yang masih berada pada kategori cenderung sedang yaitu indikator mampu mengembangkan indikator dan instrumen penilaian. 3) Kompetensi pedagogik dalam menyelenggarakan pembelajaran yang mendidik terdapat satu indikator yang masih berada pada kategori cenderung sedang yaitu mampu menggunakan media pembelajaran dan sumber belajar yang relevan dengan karakteristik peserta didik dan mata pelajaran yang diampu untuk mencapai tujuan pembelajaran secara utuh. dan 4) Kompetensi pedagogik dalam menguasai teori belajar dan prinsip-prinsip pembelajaran yang mendidik masih terdapat satu indikator yang masih berada pada kategori cenderung sedang yaitu indikator mampu menerapkan berbagai pendekatan, strategi, metode, dan teknik pembelajaran yang mendidik secara kreatif dalam mata pelajaran yang diampu.

Berdasarkan hasil penelitian dan kesimpulan penelitian di atas peneliti merekomendasikan: 1) Bagi guru sebaiknya meningkatkan kompetensi pedagogik yang masih terdapat indikator yang masih berada pada kategori cenderung sedang seperti

\footnotetext{
${ }^{41}$ Wawancara dengan bpk. Bapak Sunanto
} 
indikator mampu mengembangkan indikator dan instrumen penilaian, mampu menggunakan media pembelajaran dan sumber belajar yang relevan dengan karakteristik peserta didik dan mata pelajaran yang diampu untuk mencapai tujuan pembelajaran secara utuh dan mampu menerapkan berbagai pendekatan, strategi, metode, dan teknik pembelajaran yang mendidik secara kreatif dalam mata pelajaran yang diampu dengan mengikuti pelatihan-pelatihan kompetensi yang diadakan oleh dinas pendidikan maupun lembaga-lembaga lain yang sesuai terkait dengan upaya peningkatan kompetensi pedagogik. 2) Bagi sekolah, perlu adanya upaya memotivasi, memonitoring dan mengadakan kegiatan-kegiatan yang dapat meningkatkan kompetensi pedagogi yang dilakukan secara rutin dan berkala di dalam sekolah. 3) Bagi Dinas Pendidikan Kota Metro, perlu adanya perhatian khusus dengan mengadakan kegiatan pelatihan-pelatihan berkaitan dengan upaya peningkatan kompetensi pedagogik Guru Pendidikan Agama Islam di Kota Metro dengan menjalin kerjasama dengan stakeholder-stakeholder terkait secara rutin. 


\section{Daftar Pustaka}

Afandi, M., \& Wahyuningsih, S. (2018). Analisis Kompetensi Pedagogik Guru SD di UPTD Pendidikan Banyumanik Kota Semarang. Elementray, 6(1), 1-21.

Ahmad, M. (2018). Problematika Kompetensi Pedagogik Guru Matematika ditinjau Dari Perspektif Peserta Didik Di Smk Muhammadiyah 2 Malang. In Prosiding Seminar Nasional Pendidikan Matematika (Vol. 1).

Aldarmono, A. (2012). Identifikasi gaya kognitif (cognitive style) peserta didik dalam belajar. Al-Mabsut: Jurnal Studi Islam dan Sosial, 3(1), 63-69.

Arifin, M. (2009). Evaluasi pembelajaran mata pelajaran PAI siswa kelas IX di SMP Islam Sultan Agung Sukolilo Pati (Doctoral dissertation, UIN Walisongo).

Arikunto, S. (2006). Pengelolaan Kelas dan Siswa Pendekatan Praktek. Rineka Cipta: Jakarta.

Asep, S., \& Jihad, A. (2013). Bagaimana Menjadi calon Guru Dan Guru Professional. Yogyakarta: Multi Pressindo.

Ashsiddiqi, H. (2012). Kompetensi sosial guru dalam pembelajaran dan pengembangannya. Ta'dib: Journal of Islamic Education (Jurnal Pendidikan Islam), 17(01), 61-71.

Balqis, P., Ibrahim, N. U., \& Ibrahim, S. (2014). Kompetensi pedagogik guru dalam meningkatkan motivasi belajar siswa pada SMPN 3 Ingin Jaya Kabupaten Aceh Besar. Jurnal Administrasi Pendidikan: Program Pascasarjana Unsyiah, 2(1).

Dedih, U., \& Nurajijah, A. I. (2018). Kompetensi Paedagogik Guru Pendidikan Agama Islam Terhadap Motivasi Belajar Siswa SMP. Jurnal Perspektif, 2(1), 72-79.

Djamarah, S. B., \& Zain, A. (2002). Belajar dan pembelajaran. Jakarta: Rineka Cipta.

Dirman, D., \& Juarsih, C. (2014). Teori Belajar dan Prinsip-prinsip Pembelajaran yang Mendidik. Jakarta: Rineka Cipta.

Fitrianti, L. (2018). Prinsip Kontinuitas Dalam Evaluasi Proses Pembelajaran. AlIshlah: Jurnal Pendidikan, 10(1), 89-102.

Hamalik, O. (2006). Manajemen pengembangan kurikulum. Sekolah Pascasarjana Universitas Pendidikan Indonesia dengan PT Remaja Rosdakarya.

Hamzah, B. U. (2007). Profesi kependidikan, problema, solusi, dan reformasi pendidikan di Indonesia. Bumi Aksara: Jakarta.

Hanafy, M. S. (2014). Konsep belajar dan pembelajaran. Lentera Pendidikan: Jurnal Ilmu Tarbiyah dan Keguruan, 17(1), 66-79.

Husain, C. (2014). Pemanfaatan teknologi informasi dan komunikasi dalam pembelajaran di SMA Muhammadiyah Tarakan. Jurnal Kebijakan dan Pengembangan Pendidikan, 2(2). 
Indonesia, P. R. (2003). Undang-undang Republik Indonesia nomor 20 tahun 2003 tentang sistem pendidikan nasional. Jakarta: Pemerintah Republik Indonesia.

Mujib, A., \& Mudzakir, J. (2001). Nuasa-nuasa psikologi Islam. Raja Grafindo Persada.

Muspiroh, N. (2016). Peran Kompetensi Sosial Guru dalam Menciptakan Efektifitas Pembelajaran. Edueksos: Jurnal Pendidikan Sosial \& Ekonomi, 4(2).

Nahar, N. I. (2016). Penerapan teori belajar behavioristik dalam proses pembelajaran. NUSANTARA: Jurnal Ilmu Pengetahuan Sosial, 1(1).

Nasional, D. P. (2005). Undang-Undang nomor 14 tahun 2005, tentang guru dan dosen. Jakarta: Depdiknas.

Nasional, S. L. P. M. P. (2016). Nomor 16 Tahun 2007 Tanggal 4 Mei 2007 Standar Kualifikasi Akademik Dan Kompetensi Guru. Diposting dari http://sdm. data. kemdikbud. go. id/SNP/dokumen/Permendiknas\% 20No.

Norsidi, N., \& Paiman, P. (2018). Analisis Kompetensi Pedagogik Guru Mata Pelajaran Geografi Sekolah Menengah Atas (SMA) Sebagai Pelaksana Kurikulum 2013 Di Kabupaten Ketapang. Sosial Horizon: Jurnal Pendidikan Sosial, 5(2), 202-216.

Purwanto, S. E. (2006). Penggunaan Model Assessment Portofolio dalam Penilaian Proses dan Hasil Belajar Program Linear. Jurnal Mimbar Pendidikan.

Raharjo, S. B. (2012). Evaluasi trend kualitas pendidikan di indonesia. Jurnal Penelitian dan Evaluasi Pendidikan, 16(2), 511-532.

Ramayulis, H. (2013). Profesi dan etika keguruan. Jakarta: Kalam Mulia.

Ramadhani, W. P. (2019). Pengaruh Penggunaan Media Komik dan Motivasi Belajar terhadap Hasil Belajar Matematika Siswa SMP. JUPITEK: Jurnal Pendidikan Matematika, 2(2), 77-86.

Riandhana, T. E. (2016). Pengaruh Kompetensi Pedagogik dan Kompetensi Profesional Guru terhadap Pembelajaran IPS di SMP Negeri Kota Palu. Katalogis, 4(1).

Restiyani, R. (2014). Profil pemanfaatan teknologi informasi dan komunikasi (TIK) sebagai media dan sumber pembelajaran oleh guru biologi. EDUSAINS, 6(1), 4966.

Sriyanto, S., Murniawaty, I., Nuryana, I., \& Ismiyati, I. (2018). Peningkatan profesionalisme guru ekonomi dalam pembelajaran di SMA Kabupaten Semarang. JPPM (Jurnal Pengabdian dan Pemberdayaan Masyarakat), 2(2), 357362.

Suhandani, D., \& Julia, J. (2014). Identifikasi Kompetensi Guru Sebagai Cerminan Profesionalisme Tenaga Pendidik Di Kabupaten Sumedang (Kajian Pada Kompetensi Pedagogik). Mimbar Sekolah Dasar, 1(2), 128-141. 
Surjana, A. (2002). Efektivitas pengelolaan kelas. Jurnal Pendidikan Penabur, 1(1), 64-80.

Ulla, A. M. (2017). Analisis Kompetensi Pedagogik Guru Pada Aspek Pengembangan Kurikulum Terkait Mata Pelajaran Yang Di Ampu Melalui Rencana Pelaksanaan Pembelajaran (Studi Pada Guru Produktif Pemasaran di SMK Negeri 1 Boyolangu Tulungagung). SKRIPSI Jurusan Manajemen-Fakultas Ekonomi UM.

Widoyoko, E. P. (2009). Evaluasi program pembelajaran. Yogyakarta: pustaka pelajar, 238.

Yulianti, F. (2012). Hubungan Kompetensi Pedagogik Guru PAI dengan Prestasi Belajar pada Mata Pelajaran PAI (Studi Deskriptif pada Guru PAI di SMP Negeri Kota Indramayu). Jurnal Tarbawi, 1(2), 137.

Yusuf, Y. (2019). Problematik Guru Bahasa Indonesia Berkomunikasi secara Efektif, Empatik, dan Santun dengan Peserta Didik. Jurnal Tinta, 1(1), 71-80. 